\title{
REMUNERATION SYSTEM ELEMENTS' IMPACT ON THE PERFORMANCE OF THE TEACHERS OF GENERAL EDUCATION INSTITUTIONS IN THE REGIONS OF LATVIA
}

\author{
Ilze Prizevoite ${ }^{1,}$ Mg. oec., Gunta Grinberga-Zalite ${ }^{2}$, Dr. oec. \\ 1,2 Latvia University of Life Sciences and Technologies
}

\begin{abstract}
The authors of the article present the results of a study on the evaluation of the remuneration and performance of teachers in general education institutions in the regions of Latvia, which is a topical issue in the implementation of education system reforms. The aim of the study was to find out the opinion of teachers working in general education institutions about the factors influencing work performance, paying special attention to the regional aspects of this problem. The study used quantitative research methods through an extensive online survey. The questionnaire identified the following factors influencing teachers' performance: financial remuneration, non-financial remuneration, organizational culture and politics. The opinion of teachers was analysed in depth by regions of Latvia. The results show that in all regions of Latvia the performance of teachers is most significantly influenced by financial remuneration, nonfinancial remuneration and organizational culture are also important, but political presence plays an insignificant role. The results also revealed that in all regions (least in Riga and Pieriga) the increase of the minimum monthly wage rate of teachers or the wage is not the determining factor that would increase the performance of teachers.
\end{abstract}

Key words: education performance, regional development, regional disparities.

JEL code: $\mathrm{I} 25 ; \mathrm{H} 75$; $\mathrm{H} 52$

\section{Introduction}

The teaching profession is becoming more complex, the demands are increasing. In contrast, teachers' wages are inadequate in the light of economic change at the time. The government is demanding an increase in the quality of education alongside wage increases, emphasizing that wages go hand in hand with the quality of education. In addition, the challenges posed by digitalisation and the tensions caused by global pandemics pose new challenges to the implementation of planned education reforms (Pelse M., Lescevica M., 2020; Grinberga-Zalite G., Zvirbule A., 2020). As dissatisfaction continues, their consequences may pose a threat not only to the education system, but also, in the future context, to the public and economic sector in Latvia. No research has been conducted in Latvia so far, and therefore there is no basis for the statement that increasing the wages will improve the performance of teachers. The authors present the results of an online survey on the factors influencing the performance of general education teachers in the regions of Latvia.

The aim of the research was to find out the opinion of teachers working in general education institutions about the factors influencing work performance. Tasks of the research: 1) to identify problems in various aspects related to teachers' financial and non-financial remuneration; 2) to determine which of the factors influencing performance most increases the performance of teachers; 3) to compare the results in the regions and in Latvia in general. Hypotheses put forward in the research: 1) increase of wages is not the determining factor for increase of teachers' work performance; 2 ) factors influencing teachers' performance will not differ significantly in the regions of Latvia.

The concept of quantitative research was used, and the quantitative survey of teachers was conducted using the web tool visidati.Iv $(\mathrm{n}=603)$ from 19 September to 23 October 2020. Information about the survey was disseminated by sending an e-mail to every general education institution in Latvia, using Latvian Trade Union of Education and Science Employees organizations in schools and social media. Based on the research of the scientific literature, the authors of the questionnaire had identified the following factors influencing the performance of teachers: 1 ) financial remuneration - wage, allowances, bonuses, relief and 
benefits; 2) non-financial remuneration - appreciation, responsibility and participation, development and growth; 3) organizational culture; 4) policy. In addition to financial and non-financial remuneration, the authors made statements about the impact of teachers' performance based on the current situation in Latvia. The opinion of teachers was analysed by regions of Latvia. The teacher survey was conducted based on the methodological and ethical principles of the online survey (Roberts \& Allen, 2015; Toepoel, 2015). The survey was anonymous and the results were used only in aggregate way.

The sample of the study consisted of 603 respondents. Among the respondents, $91.5 \%$ were women and $8.5 \%$ were men. The surveyed teachers represented all statistical regions of Latvia: Vidzeme (21.8\%), Kurzeme (17.6\%), Zemgale (12.3\%), Latgale (21\%), Pieriga (12.5\%) and Riga region $(14.8 \%)$. Respondents represented primary, secondary and secondary schools, and their job position was "a teacher"; they were of different ages, thus representing different age groups.

\section{Research results and discussion}

\section{Financial remuneration}

Based on the research of the authors' scientific literature, the financial remuneration consists of 4 aspects: basic wage, allowances, bonuses, relief/benefits. In Latvia, a teacher's salary is determined according to the principle "Money follows the student" (in Latvian - "Nauda seko skolenam"). Regulations of the Cabinet of Ministers No. 445 "Regulations on Teachers' Salary" determines the procedure for determining teachers' salary, the amount of salary and the amount of teachers 'workload (Pedagogu darba samaksas noteikumi, 2016), while Cabinet of Ministers No. 447 "Regulations on State Budget Targeted Grants for Teachers' Salaries in Local Government General Education Institutions and General Secondary Education Institutions of State Higher Education Institutions" determines the procedure by which the Ministry of Education and Science distributes the state budget for teachers' salaries (Par valsts budzeta..., 2016). Analyzing these two regulatory enactments, it can be concluded that the basic wage for teachers, despite the fact that the regulatory enactments set the mimimum monthly wage rate for teachers - EUR 790 per 30-hour workload in 2020/2021, differs both in the statistical regions and counties of Latvia. As per funding model "Money follows the student", the number of additional paid duties (correction of student's works/papers, preparation for lessons, individual work with students, class education) also differs. Latvia has a relatively large number of educational institutions with a small number of students (less than 100 students), where teachers receive the minimum monthly wage rate and many educational institutions do not have enough funding to pay for all the additional duties for teachers, as funding is only enough for teachers to be paid for contact hours. There are various other factors that affect a teacher's basic wage due to the funding model. In Latvia, teachers have the opportunity to receive an allowance every month if, based on the Cabinet of Ministers No. 501 "Regulations on the Arrangements for the Organization of the Evaluation of Teachers' Professional Activities" has obtained one of the three possible quality levels. The quality level is the result of the evaluation of the teacher's professional activity, and it is valid only in the educational institution where the teacher's evaluation was performed (Pedagogu profesionalas darbibas..., 2017). Bonuses for teachers can be awarded by the director of an educational institution within the framework of the state budget paid teachers' salary fund or by the local government from its own budget. Relief, on the other hand, is designed to make work easier for employees and benefits to make work enjoyable and comfortable, support employees in important life events and promote employee motivation and loyalty to the employer. 
Figure 1 shows teachers' views on whether performance would improve if any of these aspects of financial remuneration were provided.

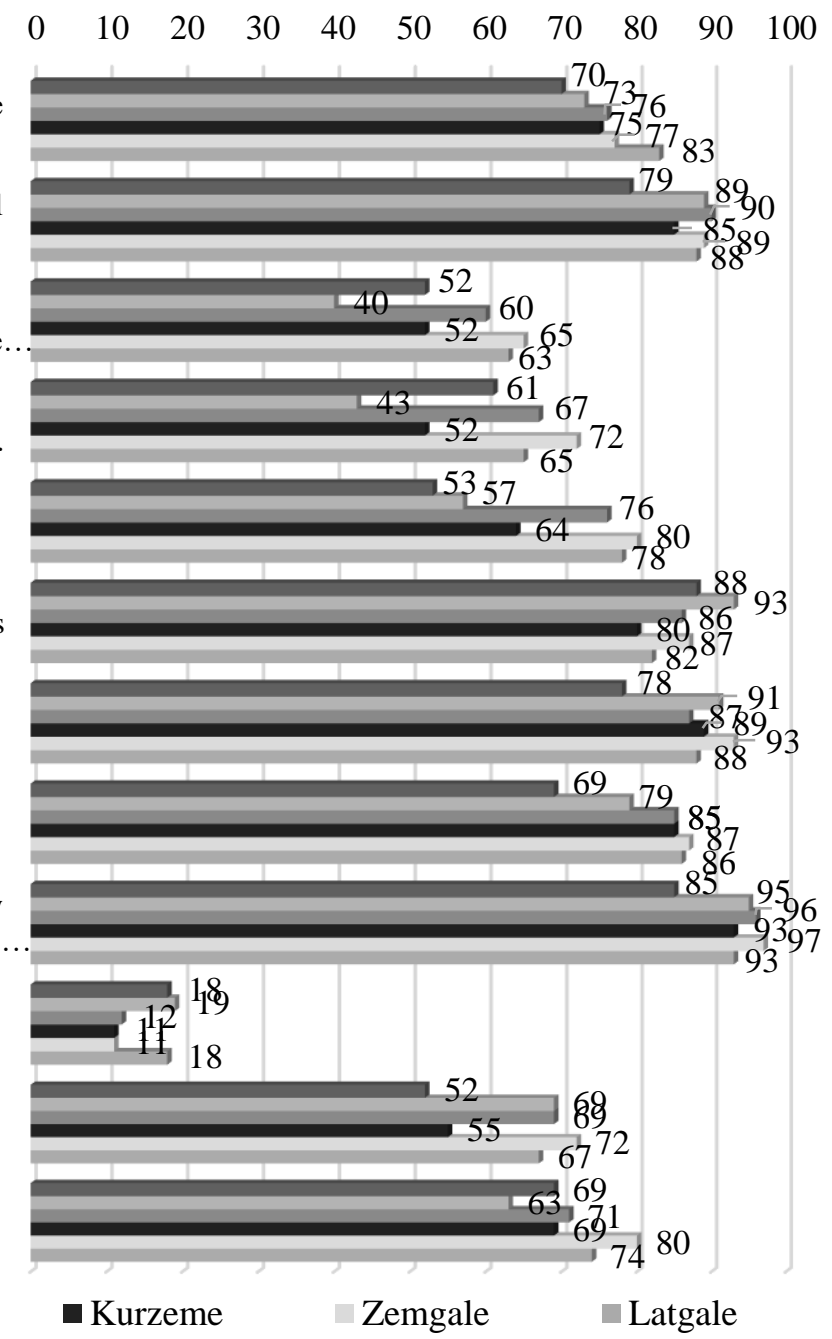

\section{Riga $\quad$ Pieriga $\quad$ Vidzeme
Source: author's calculations based on research data}

\section{Fig. 1. Teachers' opinion on financial remuneration factors that would improve work performance (optional set "yes" and "more yes than no", \%), n = 603}

According to the data of Figure 1, it can be concluded that teachers' performance would be most improved or $93 \%$ of the surveyed teachers believe that their performance would improve if students with special needs were provided with the necessary support staff assistance (teaching assistant, special teaching assistant, speech therapist, psychologist). The fact that this aspect of financial remuneration would improve the performance of teachers the most is considered by $95 \%$ of the surveyed teachers in Pieriga, Vidzeme - $96 \%$, Kurzeme - $93 \%$, Zemgale - $97 \%$ and Latgale - $93 \%$. For teachers in Riga, a smaller number of students per class would improve their work performance the most - 88 \% of the surveyed teachers. The authors would like to note that teachers working in all statistical regions of Latvia also believe that their work performance would improve if all additional duties to be performed in the educational institution were paid (correction of student's works/papers, preparation for lessons, individual work with students, class education) - especially in Latgale - $88 \%$ of the surveyed teachers, in Vidzeme - $90 \%$, in Zemgale - $89 \%$ and if teachers did not have to work in several educational institutions to ensure a full workload - especially in Zemgale - $93 \%$ of the surveyed teachers, in Kurzeme - 89 \% and in Latgale $88 \%$. In all statistical regions of Latvia, the performance of teachers would be least affected by the possibility to obtain some of the quality levels of teachers' professional activity. It is important to note that 
raising the minimum monthly wage rate of teachers in the country would increase the performance of teachers, but according to the data of the teacher survey, it can be concluded that this is not the determining factor.

\section{Non-financial remuneration}

Based on the research of the authors' scientific literature, non-financial remuneration consists of 3 aspects: appreciation, responsibility/participation, development/ growth. Figure 2 shows the teachers' views on the question: "Would your performance improve if any of the above aspects of non-financial remuneration were provided?"

Employer would provide you with the necessary professional development opportunities

There would be an opportunity to everyone to be present, to be able to express your thoughts and to be

Employer would nominate member of staff to the local council to apply for award and/or reword for...

Employer would nominate member of staff for outstanding achievements

Employer would award member of staff with the certificate on behalf of the educational institution

Employer would praise and/or express verbal appreciation in front of other members of staff

Employer would praise and/or thank member of staff personally

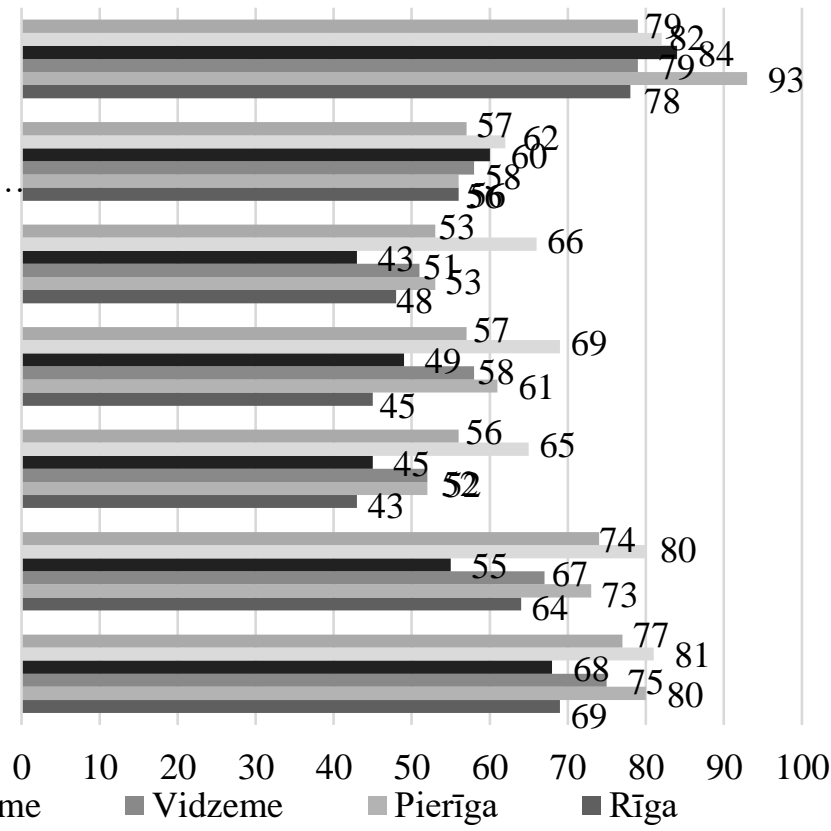

\section{Source: author's calculations based on research data}

$$
\text { Latgale Zemgale } \quad \text { Kurzeme } \quad \text { Vidzeme } \quad \text { Pierīga } \quad \text { Rīga }
$$

\section{Fig. 2. Teachers' opinion on non-financial remuneration factors that would improve work performance (optional set "yes" and "more yes than no", \%), n = 603}

In all regions of Latvia, teachers believe that among the non-financial remuneration factors, their work performance would improve the most if the employer provided the necessary professional development opportunities. The second factor that would improve the performance of teachers in all regions was recognized apprach when the employer praised or thanked them personally. On the other hand, teachers' performance would be least affected or not affected at all: in Riga (43\%) and Pieriga (52 \%) regions, if the employer awarded a certificate of thanks from an educational institution, Vidzeme (51 \%), Kurzeme (43\%) and Latgale (53\%) in the region, if the employer invited the municipality to apply for a letter of appreciation or gratitude from the Ministry of Education and Science, but in Zemgale (62 \%) region, if teachers had the opportunity to be present, freely express their thoughts and participate in important decisions.

\section{Organizational culture}

Organizational culture is what unites the people working in the organization, unites the team, greatly contributes to the effective operation of the organization. Features of organizational culture such as cohesion, unity in the organization are possible due to a stable system of norms and values.

Organizational culture is an important prerequisite, which in various studies has demonstrated important connections for organizations: 
- it affects productivity (Gregory B. T., Harris S. G., Armenakis A. A., Shook C. L., 2009);

- culture more than the organization's strategy or structure influences the quality of information flow in the organization and the understanding of the need for cooperation (Zheng W., Yang B., McLean G., 2010);

- it influences the orientation of employees towards the achievement of goals, as well as the achievement of financial goals (Homburg C., Pflesser C., 2000);

- organizational culture significantly influences employees' readiness for change and ability to accept it (Pennington G., 2003);

- it also affects the number of accidents at work (O' Toole M., 2002).

Teachers' opinion on whether work performance would improve if the head of the educational institution paid more attention to the organizational culture is shown in Figure 3.

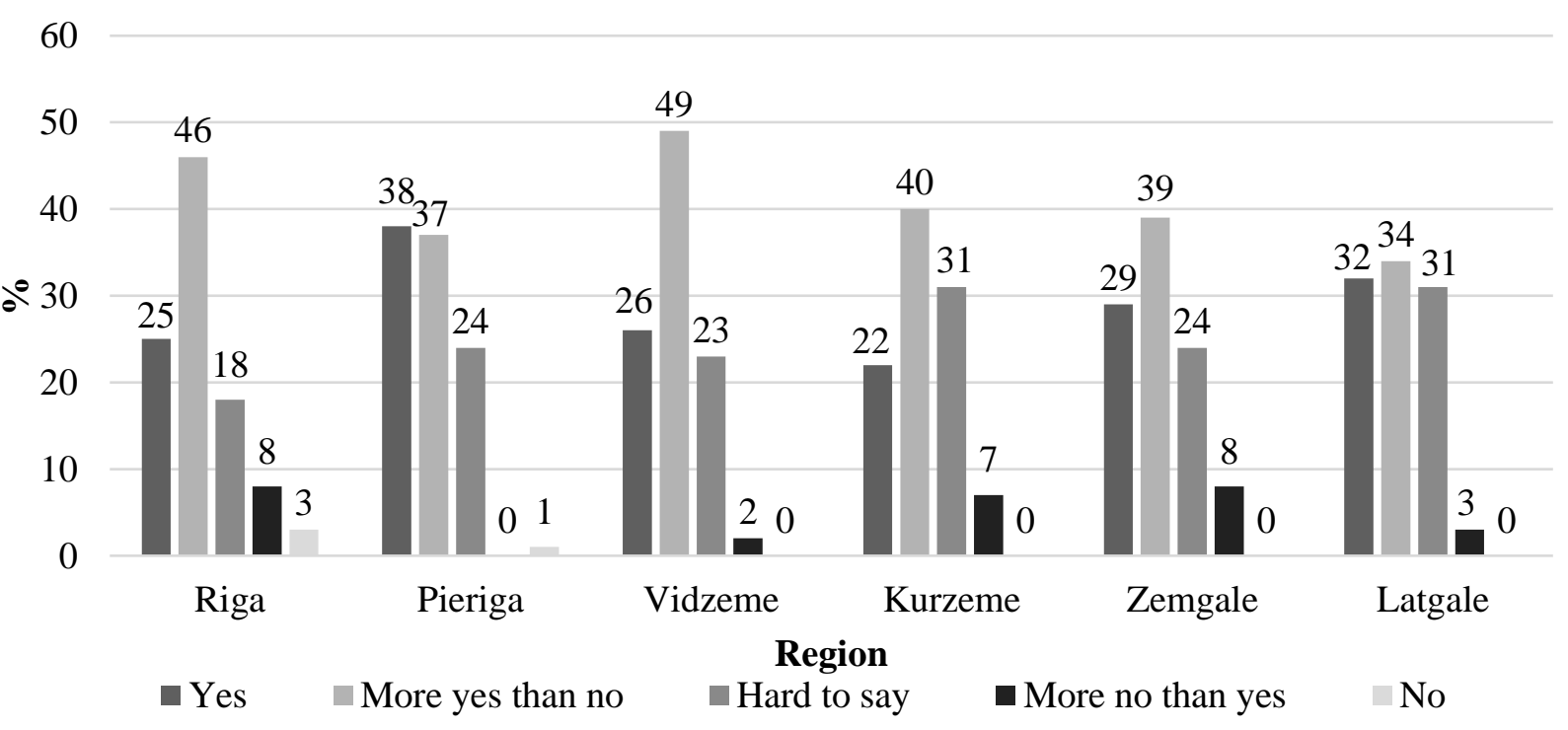

\section{Source: author's calculations based on research data}

\section{Fig. 3. Teachers' opinion on the work performance improvement if the head of the educational institution paid increased attention to the organizational culture, $\%, n=603$}

In all the regions of Latvia, the performance of teachers would improve if the head of the educational institution paid increased attention to the organizational culture: in Pieriga and Vidzeme $75 \%$ of teachers believe that their performance would improve, in Riga - $71 \%$, Zemgale - $68 \%$, Latgale - $66 \%$ and Kurzeme region $62 \%$ of teachers.

\section{Politics}

The behaviour of political leaders or leaders is related to "activities that are not necessary as part of a formal role in the organization, but that affect or attempt to influence the distribution of strengths and weaknesses in the organization" (Robbins SP, Judge TA, Millett B., Jones M., 2010). Although political behaviour is not a formal job requirement, it is nevertheless a way of life in all organizations and its performance has a significant impact on organizational performance (Robbins S.P., Judge T.A., Millett B., Jones M., 2010). Moreover, especially in the public sector, politicians are important actors in the political arena of organizations, as they have "the opportunity and ability to penetrate deeply into the internal workings of public organizations" (Pandey S., Moynihan D., 2006). In essence, they have power and are able to use their powers to influence their own or the group's interests, without regard to professionalism or the responsibility of bureaucrats in the performance of their work. Thus, J .A. Wagner III and J. R. 
Hollenbeck (2010) argued that politicians use power in public sector bureaucracy; they use their "ability to influence other people's behaviour and persuade them to do things they would not otherwise do ... and resist unwanted influences".

Figure 4 shows the data in which teachers were asked to answer the question: "Would your performance improve if there were no political presence and influence in the educational institution?"

80

60

57

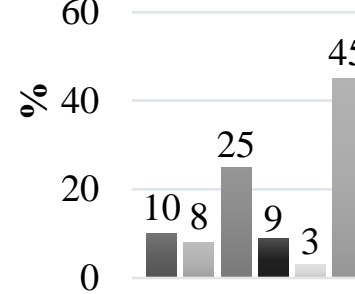

Riga

45

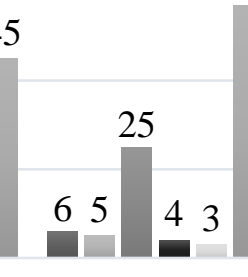

Pieriga

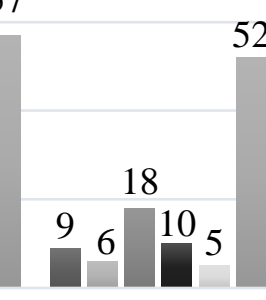

Vidzeme
52

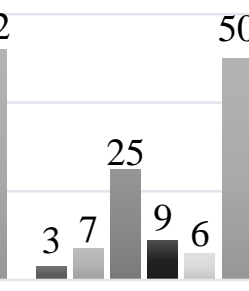

Kurzeme
60

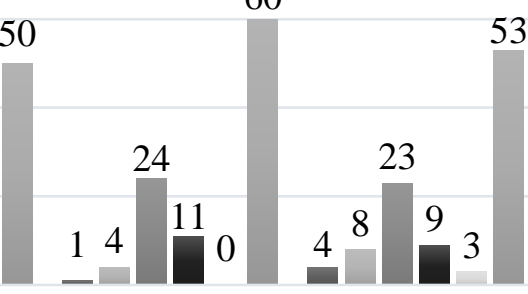

Zemgale

Latgale 53

\section{Region}

Yes

More yes than no

- Hard to say

- More no than yes

No

The political presence and its impact cannot be felt in my educational institution

\section{Source: author's calculations based on research data}

Fig. 4. Teachers' opinion on work performance improvement if there was no political presence or its influence in the educational institution, $\%, n=603$

Based on the data in Figure 4, it can be concluded that a pronounced political presence and its impact are not observed in any of the regions of Latvia. Political influence is felt most by teachers in Riga region, as $18 \%$ of teachers believe that their performance would improve if there were no political presence and influence in the educational institution, while in Zemgale - $5 \%$ of teachers.

\section{Conclusions, proposals, recommendations}

1) Among the factors influencing teachers 'performance - financial remuneration, non-financial remuneration, organizational culture and policy, the most significant influence on teachers' performance is financial remuneration. The performance of teachers in all the regions of Latvia would be most improved if students with special needs were provided with the necessary support staff assistance (teaching assistant, special teaching assistant, speech therapist, psychologist). In Latgale, $88 \%$ of the surveyed teachers, in Vidzeme - $90 \%$, in Zemgale - $89 \%$, as an important determining factor of performance is also acknowledged - if all additional duties to be performed in the educational institution (correction of student's works/papers, preparation for lessons, individual work with students, class education) and in Zemgale $93 \%$ of the surveyed teachers, in Kurzeme - $89 \%$ and in Latgale - 88 \% admit that their performance would increase if teachers did not have to work in several educational institutions to ensure full workload. $88 \%$ of the surveyed teachers in the Riga region admit that performance would increase if there was a smaller number of students in the classrooms.

2) In all statistical regions of Latvia, the performance of teachers would be least affected by the possibility to obtain some of the quality levels of teachers' professional activity.

3) Increasing the minimum monthly wage rate of teachers or the wage is not the determining factor that would increase the performance of teachers. 
4) In all the regions of Latvia, an important factor of non-financial remuneration for teachers is the approach according to which the employer provides the necessary professional development opportunities and employer praises or expresses gratitude personally.

5) Organizational culture was recognized in all the regions as an important determinant of teachers' performance, while a strong political presence and impact was not observed in any region of Latvia.

6) In order to further explore the factors influencing teachers' performance, the authors' future research will be related to the opinion of the directors and experts of the educational institution on the factors influencing teachers' performance in order to make proposals to the Ministry of Education and Science for future policy.

\section{Acknowledgement}

The paper was supported by the National Research Programme "Latvian Heritage and Future Challenges for the Sustainability of the State", project "Challenges for the Latvian State and Society and the Solutions in the International Context (INTERFRAME-LV)".

\section{Bibliography}

1. Gregory, B.T., Harris, S.G., Armenakis, A.A., Shook, C.L. (2009). Organizational Culture and Effectiveness: A Study of Values, Attitudes, and Organizational Outcomes. Journal of Business Research, Volume 62, Issue 7, pp.673-679.

2. Grinberga-Zalite, G., Zvirbule, A. (2020). Digital Readiness and Competitiveness of the EU Higher Education Institutions: The COVID-19 Pandemic Impact. Emerging Science Journal, Volume 4, Issue 4, pp.229-304.

3. Homburg, C., Pflesser, C. (2000). A Multiple-layer Model of Market-oriented Organizational Culture: Measurement Issues and Performance Outcomes. Journal of Marketing Research, Volume 37, Issue 4, pp.449462.

4. O'Toole, M. (2002). The Relationship between Employees' Perceptions of Safety and Organizational Culture. Journal of Safety Research, Volume 33, Issue 2, pp.231-243.

5. Pandey, S., Moynihan, D. (2006). Bureaucratic Red Tape and Organisational Performance: testing the moderating role of culture and political support. In Boyne G.A, Meier K.J., O'Tolle L.J., Walker R.M., eds., Public Service Performance. Cambridge: Cambridge University Press, pp.130-151.

6. Par valsts budzeta merkdotaciju pedagogu darba samaksai pasvaldibu visparejas izglitibas iestades un valsts augstskolu visparejas videjas izglitibas iestades noteikumi Nr. 447 (Regulations on State Budget Targeted Grants for Teachers' Salaries in Local Government General Education Institutions and General Secondary Education Institutions of State Higher Education Institutions No 447) (2016). Retrieved: https://likumi.lv/ta/id/283668-par-valsts-budzeta-merkdotaciju-pedagogu-darba-samaksai-pasvaldibuvisparejas-izglitibas-iestades-un-valsts-augstskolu Access: 19.02.2021.

7. Pedagogu darba samaksas noteikumi Nr. 445 (Regulations on teachers' salary No 445) (2016). Retrieved: https://likumi.Iv/ta/id/283667-pedagogu-darba-samaksas-noteikumi Access: 04.02.2021.

8. Pedagogu profesionalas darbibas kvalitates novertesanas organizesanas kartibas noteikumi Nr. 501 (Regulations on the arrangements for the organization of the evaluation of teachers' professional activities No 501) (2017). Retrieved: https://likumi.lv/ta/id/293176 Access: 14.02.2021.

9. Pelse, M... Lescevica, M. (2020). Analysis of Digitalization Referred to in Strategic Policy Documents in the Lifelong Education Context. In: Proceedings of the 21st International scientific conference "Economic science for rural development", Jelgava, May 12-15, 2020 / Latvia University of Life Sciences and Technologies. Faculty of Economics and Social Development. - Jelgava, 2020. - No 54: Home Economics, Marketing and sustainable consumption, Integrated and sustainable regional development, New dimensions in the development of society, pp. 249-257.

10. Pennington, G. (2003). Guidelines for Promoting and Facilitating Change. Higher Education Academy: Learning and Teaching Support Network Generic Centre.

11. Robbins, S.P., Judge, T.A., Millett, B., Jones, M. (2010). OB: The Essentials. Australia, Sydney: Pearson Higher Education.

12. Roberts, D. L. \& Allen, J. p. (2015). Exploring Ethical Issues Associated with Using Online Surveys in Educational Research. Educational Research and Evaluation, 21(2), pp. 95-108.

13. Toepoel, V. (2015). Doing Surveys Online. London: Sage Publications, 280 p.

14. Wagner III, J.A., Hollenbeck, J.R. (2010). Organisational Behaviour: Securing Competitive Advantage. New York: Routledge.

15. Zheng, W., Yang, B., McLean, G. (2010). Linking Organizational Culture, Structure, Strategy, and Organizational Effectiveness: Mediating role of knowledge management. Journal of Business Research, Volume 63, Issue 7, pp.763-771. 